\title{
PENGARUH EKSTRAK TEMPE TERHADAP MEKANISME DAN LAJU PERUBAHAN $\beta$-KAROTEN DALAM SAUS CABE
}

\author{
Saifuddin Sirajuddin ${ }^{1}$ dan Masni ${ }^{1}$ \\ ${ }^{1}$ Fakultas Kesehatan Masyarakat Universitas Hasanuddin Makassar
}

\section{ABSTRACT \\ THE EFFECT OF TEMPE EXTRACT ON THE MECHANISM AND RATE OF CHANGES OF B-CAROTEN IN CHILI SAUCE}

\begin{abstract}
Chili sauce has the potential to be used as a vehicle for vitamin A fortification in the form of $\beta$ carotene, since it can be added to various foods. However, we need information about the resistance of $\beta$-carotene in chili sauce during processing and storage. The objectives of this study are: to identify the degradation patterns of $\beta$-carotene in chili sauce which contains tempe extract in various concentration during processing and storage in room temperature, and to identify the mathematics model of $\beta$-carotene degradation. This study consists of three steps: preparing tempe extract using tempe inoculum; preparing chili sauce; and analysis of changes of $\beta$-carotene in chili sauce during processing and storage.

The results of this study are: the tempe produced rendement extract of $14,18 \%$ with 3 hydroxianthranilic acid concentration of $33,5 \mathrm{mg} / 100$ grams dried tempe; tempe extract was able to inhibit the changes of $\beta$-carotene in chili sauce caused by heating and storage in room temperature; $\beta$-carotene changes in chili sauce during storage in room temperature with and without tempe extract are following the null reaction order; mathematics model of $\beta$-carotene changes in chili sauce during room temperature storage can be used to determine $\beta$-carotene concentrations in storage time intervals through kinetic reaction analysis.
\end{abstract}

Keywords: chili sauce, tempe extract, $\beta$-carotene, fortification

\section{PENDAHULUAN}

S aus cabe termasuk produk olahan cabe, diduga mempunyai peluang cukup tinggi untuk dijadikan sebagai wahana fortifikasi vitamin $A$ dalam bentuk $\beta$ karoten. Praduga tersebut didasarkan atas: (1) saus cabe digunakan masyarakat sebagai pemberi rasa pedas pada beberapa jenis makanan termasuk makanan jajanan mie dan bakso yang sangat digemari anakanak perkotaan dan pedesaan, (2) warna saus cabe berasal dari kandungan karotenoid cabe, sehingga penggunaan $\beta$ karoten tidak berdampak negatif terhadap penampakan warna saus cabe.

B-karoten terdapat secara alami pada bahan nabati ${ }^{1}$ termasuk cabe merah dan cabe rawit $^{2}$ dapat diproduksi secara fermentasi menggunakan medium limbah industri $^{3,4}$ dan limbah pertanian ${ }^{5}$. B-karoten dalam bahan pangan mudah rusak karena oksidasi dan pengolahan dengan panas.
Chen (1996), melaporkan pemanasan jus wortel pada suhu pasteurisasi dan sterilisasi berakibat terhadap penurunan $\beta$-karoten dan perubahan geometri dari bentuk trans ke bentuk cis $^{6}$. Lidiawati (1997) menemukan warna saus cabe merah mengalami perubahan selama penyimpanan². Perubahan warna tersebut diduga berasal dari perubahan kandungan karotenoid cabe merah. Mappiratu (1992) melaporkan karotenoid pada cabe merah (termasuk $\beta$ karoten) mengalami degradasi pada proses pengeringan ${ }^{3}$. Degradasi tersebut terhambat oleh adanya antioksidan sintetik BHA dan BHT. Kerusakan $\beta$-karoten dalam pemasakan ekstrusi terhambat oleh adanya antioksidan a-Tokoferol dan antioksidan $\mathrm{BHT}^{7}$.

Esaki (1996) melaporkan tempe yang dibuat dari kacang kedele dengan inokulum kapang Rhizopus oligosporus mengandung senyawa antioksidan asam 3-hidroksi antranilat dengan aktivitas yang relatif lebih 
tinggi dibandingkan dengan a-Tokoferol dan antioksidan sintetik $\mathrm{BHT}^{8}$. Tempe juga telah dilaporkan mengandung komponen bioaktif antibakteri dan anti jamur ${ }^{9}$. Keadaan tersebut menimbulkan praduga ekstrak tempe dalam saus cabe dapat menghambat kerusakan $\beta$ karoten akibat oksidasi. Untuk itu diperlukan penelitian untuk mengkaji peranan ekstrak tempe dalam menekan kerusakan $\beta$-karoten dalam saus cabe selama penyimpanan suhu ruang. Tujuannya ádalah untuk mendapatkan informasi tentang pola kerusakan $\beta$-karoten dalam saus cabe yang mengandung ekstrak tempe pada bebagai tingkat kepekatan selama pengolahan dan penyimpanan suhu ruang, dan bentuk matematik kerusakan $\beta$-karoten tersebut yang dapat dijadikan indikator untuk memprediksi kadar $\beta$-karoten pada kurun waktu tertentu.

\section{METODE PENELITIAN}

Penelitian ini dilakukan dengan menggunakan tiga tahapan kerja, yakni pembuatan ekstrak tempe, pembuatan saus cabe, dan analisis $\beta$-karoten.

\section{A. Tahap Pembuatan Ekstrak Tempe}

Ekstrak tempe dibuat menggunakan metode Esaki (1996) yang dimodifikasi dengan diagram alir tahapan kerja mengikuti Gambar 1. Kacang kedelai yang diperoleh dari pasaran direndam dalam larutan 0,85\% asam laktat selama 24 jam, kemudian dihilangkan kulit arinya. Kacang kedelai yang telah bebas dari kulit ari direbus dalam larutan 0,85 persen asam laktat selama 60 menit, kemudian ditiriskan dan didinginkan. Kacang kedelai selanjutnya diinokulasi dengan inokulum biang tempe yang juga diperoleh dari pasaran, kemudian diinkubasi pada suhu ruang selama selama 48 jam dalam wadah plastik yang berlubang (untuk suplai udara). Tempe yang dihasilkan selanjutnya diiris setipis mungkin kemudian dikeringkan dibawah sinar matahari selama 2 - 3 hari. Irisan tempe kering selanjutnya digiling dan diayak dengan ayakan 40 mesh untuk mendapatkan tempe dalam bentuk tepung. Tepung tempe tersebut selanjutnya diekstraksi dengan pelarut etanol $95 \%$ yang dilanjutkan dengan penguapan pelarut secara vakum menggunakan rotary vakum evasporator. Ekstrak bebas pelarut yang diperoleh disimpan dalam lemari pendingin sebelum digunakan dan dianalisis kandungan asam 3-hidroksi antranilat menggunakan metode spektrofotometri.

\section{B. Tahap Pembuatan Saus Cabe}

Pembuatan saus cabe mengikuti cara Lidiawati (1997) yang dimodifikasi sebagaimana tersaji pada Gambar 2. Untuk mengetahui pengaruh ekstrak tempe terhadap kerusakan $\beta$-karoten pada proses pengolahan dan penyimpanan digunakan ekstrak tempe dengan konsentrasi bervariasi, masing-masing $0,9,18,27$, dan $36 \mathrm{~mL} / \mathrm{kg}$ cabe tanpa biji. B-karoten yang ditambahkan ke dalam saus cabe sebesar $500 \mathrm{mg} / 1,5 \mathrm{~kg}$ cabe tanpa biji. Pengamatan terhadap kadar total $\beta$-karoten dilakukan menggunakan metode spektrofotometri (Mappiratu, 1990). Pengamatan tersebut dilakukan terhadap saus cabe yang tidak mengalami pemanasan (kontrol atau pembanding), saus cabe yang telah mengalami proses pemanasan sebelum penyimpanan (nol hari) dan setelah penyimpanan selama 63 hari dengan selang waktu pengamatan 7 hari. Perlakuan di ulang dua kali sehingga jumlah unit percobaan $5 \mathrm{x}$ $10 \times 2=100$ unit percobaan. Hasil pengamatan pada selang waktu 0 hari sampai hari ke 49 digunakan untuk mendapatkan model matematik perubahan $\beta$-karoten selama penyimpanan, sedangkan hasil pengamatan pada hari ke-56 dan hari ke-63 digunakan untuk menguji validitas model matematika yang diperoleh. Pengamatan kadar total $\beta$-karoten sebelum dilakukan pemanasan dimaksudkan untuk mengetahui pengaruh pemanasan terhadap kerusakan $\beta$-karoten.

\section{Tahap Analisis}

\section{Analisis Asam 3-Hidroksi Antranilat dalam Ekstrak Tempe}

Analisis (penentuan kadar) asam 3hidroksi antranilat dalam ekstrak tempe dilakukan menggunakan metode 
spektofotometri. Ekstrak tempe diekstraksi dengan pelarut $0,1 \%$ TFA $/ 50 \%$ methanol, kemudian dipusingkan pada $3000 \mathrm{rpm}$ dan didekantasi untuk mendapatkan larutan sample. Larutan sample diencerkan dengan pengenceran 10 kali setelah volume sample ditepatkan dalam labu ukur $100 \mathrm{~mL}$, kemudian diukur serapannya pada panjang gelombang $300 \mathrm{~nm}$. Panjang gelombang serapan maksimum ditentukan menggunakan larutan standar asam 3hidroksi antranilat. Kadar asam 3-hidroksi antranilat dalam ekstrak tempe ditentukan menggunakan kurva baku yang dibuat dari larutan asam 3-idroksi antranilat pada berbagai konsentrasi, yaitu kurva hubungan antara nilai serapan terhadap konsentrasi asam 3-hidroksi antranilat.

\section{Analisis B-karoten}

Analisis $\beta$-karoten dalam saus cabe diawali dengan ekstraksi pelarut menggunakan pelarut campuran heksana/aseton (2 : $1 \mathrm{v} / \mathrm{v})$, (Mappiratu, 1992). Ekstrak yang diperoleh disaponikasi dengan larutan kalium hidroksida $20 \%$ dalam pelarut metanol $85 \%$. Saponifikasi berlangsung selama 24 jam dalam keadaan gelap. Sabun yang terbentuk dipisahkan secara dekantasi, kemudian filtrat yang diperoleh diekstraksi ulang menggunakan pelarut heksana. Ekstrak karoten dalam heksana dibebaskan dari air dengan menggunakan natrium sulfat anhidrat. Ekstrak karoten dalam pelarut heksana diencerkan dan ditepatkan volumenya dalam labu ukur $100 \mathrm{~mL}$, kemudian diukur serapannya pada panjang gelombang 450 nm. Kadar $\beta$-karoten dalam ekstrak ditentukan menggunakan kurva baku $\beta$ karoten, yaitu kurva hubungan antara nilai serapan (A) terhadap konsentrasi $\beta$-karoten standar yang diukur pada panjang gelombang $450 \mathrm{~nm}$.

\section{Analisis Data}

Data hasil pengukuran kadar $\beta$-karoten dalam saus cabe pada berbagai waktu penyimpanan digunakan untuk menentukan laju perubahan $\beta$-karoten selama penyimpanan. Kadar total $\beta$-karoten dialurkan terhadap waktu simpan saus cabe. Slop dari garis kurva merupakan laju reaksi degradasi $\beta$-karoten dalam saus cabe.

Untuk mengetahui orde reaksi perubahan $\beta$-karoten dilakukan dengan cara mengalurkan nilai kadar $\beta$-karoten dalam saus cabe terhadap waktu simpan untuk uji reaksi orde nol, nilai In kadar $\beta$-karoten terhadsp waktu simpan untuk uji reaksi orde satu, dan nilai $1 /$ kadar $\beta$-karoten terhadap waktu simpan untuk uji reaksi orde dua. Kurva yang menunjukkan kurva garis lurus merupakan keberlakuan orde reaksi perubahan $\beta$-karoten dalam saus cabe.

Hubungan antara laju reaksi dengan ekstrak tempe dianalisis secara statistik untuk mendapatkan model matematik dari hubungan antara laju reaksi dengan konsentrasi ekstrak tempe (dalam hal ini konsentrasi asam 3-hidroksi antranilat), yaitu melalui persamaan regresi. Model matematik yang dihasilkan diuji validitasnya menggunakan data kadar $\beta$-karoten pada penyimpanan hari ke 56 dan hari ke 63.

\section{HASIL DAN BAHASAN}

\section{A. Asam 3-Hidroksi Antranilat dalam Ekstrak Tempe}

Fermentasi biji kacang kedelai menggunakan inokulum kapang Rizopus.sp (kapang tempe) menghasilkan tempe dengan pertumbuhan kapang yang relatif baik. Hal tersebut ditandai dari pertumbuhan miselium berwarna putih yang tumbuh secara merata pada permukaan tempe. Perlakuan awal yang diterapkan dalam upaya untuk mendapatkan keterangan tentang kandungan asam 3-hidroksi antranilat (AHA) dalam ekstrak tempe adalah pengirisan dan pengeringan irisan tempe dengan sinar matahari, yang dilanjutkan dengan penepungan dan ekstraksi menggunakan pelarut etanol $95 \%$. Perlakuan ini menghasilkan ekstrak tempe berwarna merah dengan rendemen ekstrak $14,18 \%$. Warna merah ekstrak kemungkinan disebabkan oleh pigmen yang ada pada biji kedelai yang besifat larut dalam etanol. Pigmen warna merah tersebut bukan dari $\beta$ - 
karoten, sebab $\beta$-karoten tidak larut dalam pelarut yang bersifat polar seperti etanol ${ }^{3}$.

Nilai rendemen ekstrak sebesar 14,18 $\%$ memberi keterangan komponen kimia tempe yang larut dalam pelarut etanol relative rendah, hanya sekitar $14 \%$ dari komponen kimia tempe yang ada. Selain itu, rendemen ekstrak tersebut juga memberi gambaran jumlah volume ekstrak yang dapat dihasilkan untuk setiap kilogram tempe kering sinar matahari, yaitu sekitar $140 \mathrm{~mL}$.

Untuk mendapatkan keterangan kadar asam 3-hidroksi antranilat dalam ekstrak tempe yang dihasilkan, dilakukan analisis menggunakan metode spektrofotometri. Hasil pengukuran nilai serapan larutan standar dan ekstrak tempe tersaji pada Tabel 1.

\section{B. B-karoten Dalam Saus Cabe}

B-karoten yang memiliki fungsi sebagai antioksidan sangat peka terhadap kerusakan oksidasi, baik yang disebabkan oleh panas selama pengolahan (termal oksidasi) maupun disebabkan oleh cahaya selama penyimpanan suhu ruang (fotooksidasi). Berdasarkan hal tersebut terdapat peluang $\beta$-karoten dalam saus cabe mengalami degradasi selama pengolahan dengan panas dan selama penyimpanan suhu ruang. Demikian pula kerusakan $\beta$-karoten dalam saus cabe sangat mungkin terhambat oleh adanya senyawa lain yang juga bersifat sebagai antioksidan.

Untuk mengetahui kerusakan $\beta$-karoten dalam saus cabe selama penyimpanan dan fungsi ekstrak tempe menekan kerusakan tersebut, dilakukan analisis $\beta$-karoten dalam saus cabe yang belum mengalami pemanasan dan yang telah mengalami pemanasan dengan dan tanpa penambahan ekstrak tempe. Analisis dilakukan menggunakan metode spektrofotometri, dimana kadar $\beta$-karoten dalam sampel ditentukan melalui kurva baku seperti tersaji pada Gambar 3. Hasil analisis (Tabel 2) memberi keterangan bahwa $\beta$-karoten dalam saus cabe yang tidak mengandung ekstrak tempe mengalami penurunan yang cukup berarti, sedangkan yang mengandung ekstrak tempe penurunannya semakin kecil dengan meningkatnya kadar ekstrak tempe. Keadaan tersebut mengandung arti ekstrak tempe memiliki kemampuan mencegah kerusakan $\beta$-karoten dalam saus cabe selama pengolahan dengan panas.

Tabel 2 menunjukkan bahwa, pada penambahan ekstrak tempe sebanyak 36 $\mathrm{mL} / \mathrm{kg}$ cabe tanpa biji, kadar $\beta$-karoten dalam saus cabe tidak memberikan perbedaan yang berarti dibandingkan kadar $\beta$-karoten dalam saus cabe yang tidak dipanaskan (kontrol). Keadaan tersebut memberi petunjuk bahwa, dengan penambahan ekstrak tempe sebanyak $36 \mathrm{~mL}$ yang setara dengan $84,96 \mathrm{mg}$ AHA $/ \mathrm{kg}$ cabe tanpa biji telah mampu mempertahankan kerusakan $\beta$ karoten yang disebabkan karena panas atau menghambat kerusakan termal oksidasi $\beta$ karoten dalam saus cabe.

Untuk mengetahui pola penghambatan ekstrak tempe terhadap kerusakan termal oksidasi $\beta$-karoten dalam saus cabe, dibuat kurva hubungan antara jumlah $\beta$-karoten yang terdegradasi dalam satuan persen kerusakan terhadap kadar ekstrak tempe dalam saus cabe seperti tersaji pada Gambar 3. Gambar 3 menunjukkan bahwa pola perubahan $\beta$-karoten cenderung mengikuti garis kurva linier pada konsentrasi ekstrak tempe yang rendah, dan mengikuti garis kurva yang mendatar pada konsentrasi ekstrak tempe yang relatif tinggi. Keadaan tersebut memberi indikasi adanya kesebandingan antara kadar $\beta$-karoten saus cabe dengan kadar asam 3-hidroksi antranilat dalam ekstrak tempe. Pada konsentrasi asam 3-hidroksi antranilat yang setara atau lebih tinggi, $\beta$-karoten akan terhambat atau terlindungi dari kerusakan termal oksidasi dalam arti yang mengalami oksidasi sepenuhnya asam 3-hidroksi antranilat, sedangkan pada konsentrasi yang lebih rendah asam 3-hidroksi antranilat tidak mampu melindumngi sepenuhnya $\beta$-karoten dari kerusakan termal oksidasi.

Dengan pola perubahan tersebut terdapat praduga kandungan $\beta$-karoten dalam saus cabe sebanyak $225 \mathrm{mg} / \mathrm{kg}$ saus cabe telah mencapai kesetaraan dengan kandungan asam 3-hidroksi antranilat 56,7 $\mathrm{mg} / \mathrm{kg}$ saus cabe atau $85 \mathrm{mg} / \mathrm{kg}$ cabe tanpa 
biji, atau rasio asam 3-hidroksi antranilat/ $\beta$ karoten yang dapat menghambat kerusakan $\beta$-karoten dalam saus cabe secara sempurna sekitar 57/225 atas dasar berat/berat.

Untuk mengetahui kemampuan ekstrak tempe menghambat kerusakan $\beta$-karoten dalam saus cabe selama penyimpanan suhu ruang, dilakukan analisis $\beta$-karoten saus cabe yang tersimpan pada suhu ruang selama 63 hari dengan selang waktu analisis 7 hari. Hasil yang diperoleh (Tabel 3) menunjukkan kadar $\beta$-karoten dalam saus cabe mengalami penurunan selama penyimpanan. Penurunan tersebut semakin kecil sejalan dengan peningkatan kadar ekstrak tempe dalam saus cabe. Keadaan tersebut memberi keterangan ekstrak tempe menghambat kerusakan $\beta$-karoten dalam saus cabe yang tersimpan pada suhu ruang.

Analisis terhadap retensi $\beta$-karoten dalam saus cabe selama penyimpanan (Tabel 4) memberi keterangan nilai retensi $\beta$ karoten saus cabe yang tidak mengandung ekstrak tempe pada penyimpanan selama 63 hari adalah 30,06 \%, sedangkan yang mengandung ekstrak tempe, retensi $\beta$ karoten mencapai $88,46 \%$. Dengan demikian saus cabe yang tidak diberi ekstrak tempe mengalami kehilangan $\beta$-karoten sekitar $70 \%$, sedangkan yang mengandung ekstrak tempe sebanyak $36 \mathrm{~mL} / \mathrm{kg}$ cabe tanpa biji mengalami kehilangan $\beta$-karoten sekitar $12 \%$. Kehilangan $\beta$-karoten sebesar $12 \%$ tersebut memberi petunjuk penambahan ekstrak tempe sebanyak 36 $\mathrm{mL} / \mathrm{kg}$ cabe tanpa biji belum mampu menghambat kerusakan $\beta$-karoten saus cabe secara sempurna.

\section{Kinetika B-karoten Dalam Saus \\ Cabe}

Perubahan $\beta$-karoten dalam saus cabe selama penyimpanan dapat diprediksi melalui pengkajian kinetika perubahan $\beta$ karoten. Kajian kinetika perubahan $\beta$-karoten akan menghasilkan suatu bentuk persamaan matematik yang dapat digunakan untuk memperkirakan waktu simpan saus cabe saat $\beta$-karoten telah habis terdegradasi, atau kadar $\beta$-karoten saus cabe pada kurun waktu tertentu.
Kajian $\beta$-karoten dalam saus cabe diawali dengan analisis orde reaksi melalui kurva perubahan $\beta$-karoten relatif terhadap waktu simpan saus cabe. Sehubungan dengan hal tersebut dilakukan uji kesesuaian kurva terhadap orde reaksi, masing-masing orde reaksi nol, orde reaksi satu dan orde reaksi dua sesuai persamaan orde reaksi berikut
$\mathrm{A}=\mathrm{Ao}-\mathrm{kt} \quad$ untuk orde reaksi nol
$\ln A=\ln A_{0}-k t \quad$ untuk orde reaksi satu
$1 / A=1 / A_{0}+k t \quad$ untuk orde reaksi dua

di mana:

$A=$ konsentrasi $\beta$-karoten pada waktu $t$

Ao $=$ konsentrasi $\beta$-karoten awal

$\mathrm{k}=$ tetapan laja reaksi

$\mathrm{t} \quad$ = waktu reaksi dalam hal ini sama dengan waktu penyimpanan saus cabe

Dengan mengalurkan kadar $\beta$-karoten dalam saus cabe $(A)$ relatif terhadap waktu simpan (t) diperoleh kurva yang tersaji pada Gambar 4. Demikian pula kadar $\beta$-karoten dalam satuan In konsentrasi (In) dan 1/konsentrasi $\beta$-karoten (1/A) terhadap waktu simpan saus cabe, diperoleh kurva yang tersaji pada Gambar 5 dan 6. Pada Gambar 4, teramati garis kurva yang mengikuti persamaan linier yang berarti sesuai dengan persamaan reaksi orde nol, sedangkan garis kurva pada Gambar 5 dan 6 tidak sepenuhnya mengikuti persamaan linier sesuai dengan persamaan orde reaksi satu dan dua. Dengan demikian perubahan $\beta$ karoten dalam saus cabe cenderung mengikuti reaksi orde nol.

Dengan berpedoman pada persamaan kinetika reaksi orde nol $(A=A o-k t)$ yang mengikuti persamaan garis lurus atau persamaan linier, nilai tetapan laju reaksi $(k)$ dapat ditemukan melalui analisis regresi sebagaimana tersaji pada Tabel 5 . Demikian pula persamaan matematik perubahan $\beta$ karoten saus cabe pada penyimpanan suhu ruang juga tersaji pada Tabel 5 .

Tabel 5 menunjukkan bahwa nilai tetapan laju reaksi (k) menurun sejalan dengan meningkatnya konsentrasi ekstrak tempe dalam saus cabe. Pada reaksi orde nol, laju reaksi tidak tergantung pada 
konsentrasi substrat atau reaktan, sehingga laju reaksi sama dengan tetapan laju reaksi. Dengan demikian keberadaan ekstrak tempe dalam saus cabe berperanan menghambat laju degradasi $\beta$-karoten. Selain itu juga teramati nilai $r$ (keeratan hubungan antara kadar $\beta$-karoten dengan waktu simpan saus cabe) mendekati satu, yang berarti memperkuat dugaan perubahan $\beta$-karoten saus cabe cenderung mengikuti orde reaksi nol.

Untuk mengetahui derajat validitas persamaan matematik yang dihasilkan melalui kinetika reaksi perubahan $\beta$-karoten dalam saus cabe, dicoba menggunakan persamaan yang dihasilkan untuk menghitung kadar $\beta$-karoten dalam saus cabe pada penyimpanan 56 dan 63 hari. Hasil perhitungan dibandingkan dengan hasil pengamatan memberi indikasi bahwa, persamaan matematik yang diperoleh cukup valid digunakan untuk menghitung atau menentukan kadar $\beta$-karoten pada waktu penyimpanan tertentu. Hal tersebut terlihat dari kecilnya perbedaan antara hasil perhitungan dengan hasil pengamatan sebagaimana tersaji pada Tabel 6 .

\section{SIMPULAN}

Berdasarkan hasil penelitian dapat disimpulkan:

1. Tempe yang diproses menggunakan inokulum tempe menghasilkan rendemen ekstrak 14,18\% dengan kadar asam 3-hidroksi antranilat 33,6 $\mathrm{mg} / \mathrm{kg}$ tempe kering

2. Ekstrak tempe dalam saus cabe mampu menghambat perubahan $\beta$-karoten saus cabe yang disebabkan karena pengolahan panas. Penghambatan secara sempurna tercapai pada penggunaan ekstrak tempe $36 \mathrm{~mL} / \mathrm{kg}$ cabe tanpa biji yang setara dengan 56,7 $\mathrm{mg}$ asam 3-hidroksi antranilat/kg saus cabe.

3. Ekstrak tempe menghambat laju degradasi $\beta$-karoten dalam saus cabe selama penyimpanan suhu ruang.
4. Perubahan $\beta$-karoten dalam saus cabe yang tersimpan pada suhu ruang dengan dan tanpa penambahan ekstrak tempe mengikuti reaksi orde nol

5. Persamaan matematik perubahan $\beta$ karoten dalam saus cabe yang dihasilkan dapat digunakan untuk memprediksi kadar $\beta$-karoten dalam saus cabe selama penyimpanan suhu ruang

\section{REKOMENDASI}

Berdasarkan hasil yang diperoleh, disarankan untuk melakukan kajian lanjut kemampuan ekstrak tempe mencegah kerusakan $\beta$-karoten dalam saus cabe yang tersimpan pada suhu yang berbeda

\section{RUJUKAN}

1. Stipanuk H. Martha.,Biochemical, Physiological, Molecular Aspects of Human Nutrition. USA, 2006.

2. Lidiawati, E. Kajian aspek Teknologi Produk-produk Olahan Cabe Merah. Skripsi. Bogor: Fakultas Teknologi Pertanian, 1997.

3. Mappiratu., Produksi B-karoten pada Limbah Cair Tapioka dengan Kapang Oncom Merah. Majalah IImiah Gagasan Universitas Tadulako Palu, 1992. No. 2 Tahun VII. $78-81$.

4. Nuraida, L., S.H. Sihombing dan S. Fardiaz.. Produksi Karotenoid pada Limbah Cair Tahu, Air Kelapa dan Onggok oleh Kapang Neurospora sp. Bul. Teknol. Dan Ind. Pangan, 1996. 7 (1):67 - 74 .

5. Nuraida, L., H. T. Pardede dan S. Fardiaz.. Pemanfaatan Ampas tapioca, Ampas Tahu dan Dedal Padi untuk Produksi Karotenoid dari Nuerospora sitophilia dengan Sistem Fermentasi Padat. Prosiding Pertemuan IImiah Tahunan Perhimpunan Mikrobiologi Indonesia.Cabang.. Bogor. 1994, 354 363. 
6. Chen, B.H., H.Y. Peng dan H.E. Chen. Changes of Carotenoids, Color, and Vitamin A Contents During Processing of Carrot Juice. J. Agric. Food Chem, 1996. 43, 1912 - 1918.

7. Davidek, J., J. Velisek dan J. Pokorny.. Chemical Changes During Food Processing, New York: Elsevier Amsterdam-Oxford, 1990.
8. Esaki, H, H. Onozaki, S. Kawakishi dan T. Osawa. New Antioxidant Isolated from Tempeh. J. Agric. Food Chem, 1996. $44: 1996,697-700$.

9. Siregar, E dan Jamil. Pengujian Antifungi Ekstrak Tempe terhadap Pertumbuhan Fungi Fusarum graminearum dan Fusarum avenaceum. Prosiding Perhimpunan Mikrobiologi Indonesia Cabang Bogor, 10 Desember 1994. 


\section{LAMPIRAN}

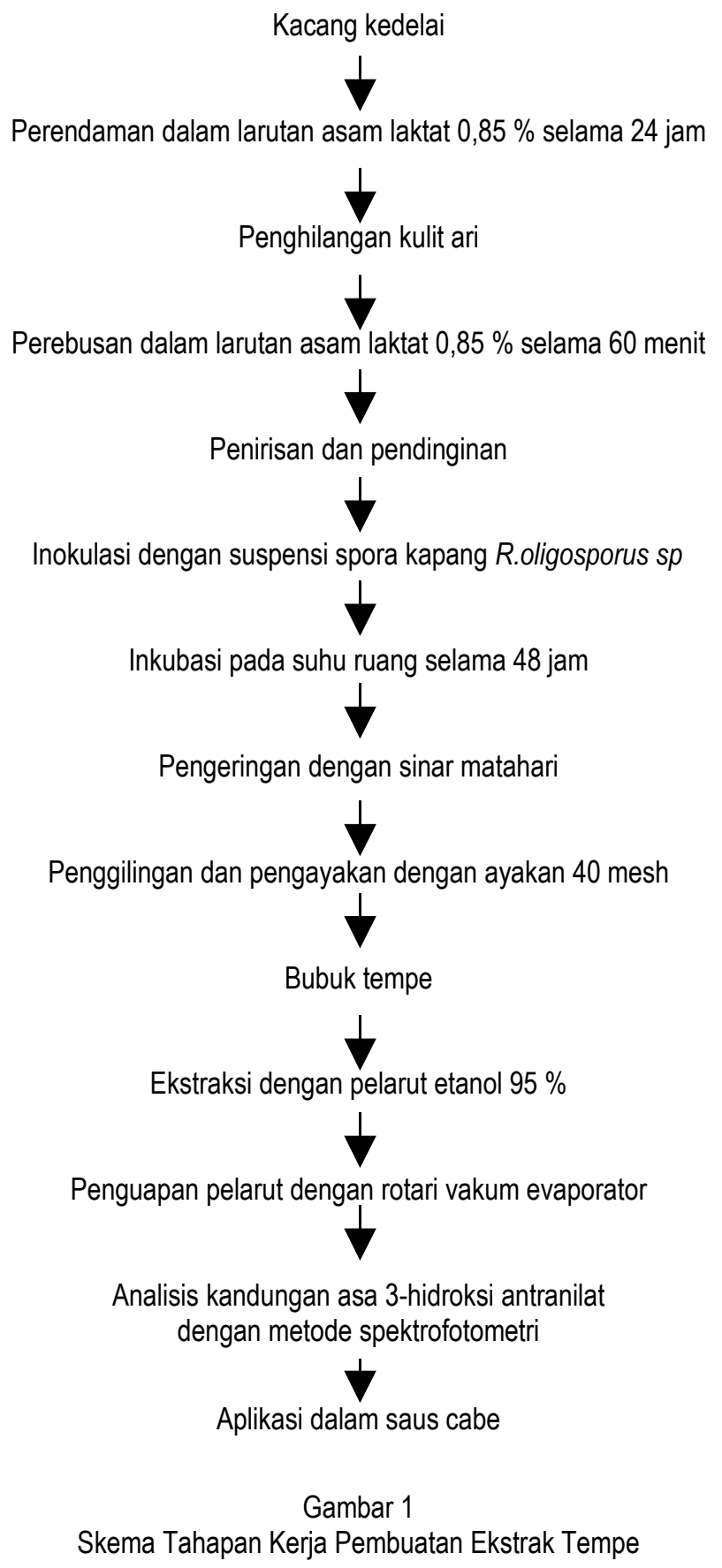




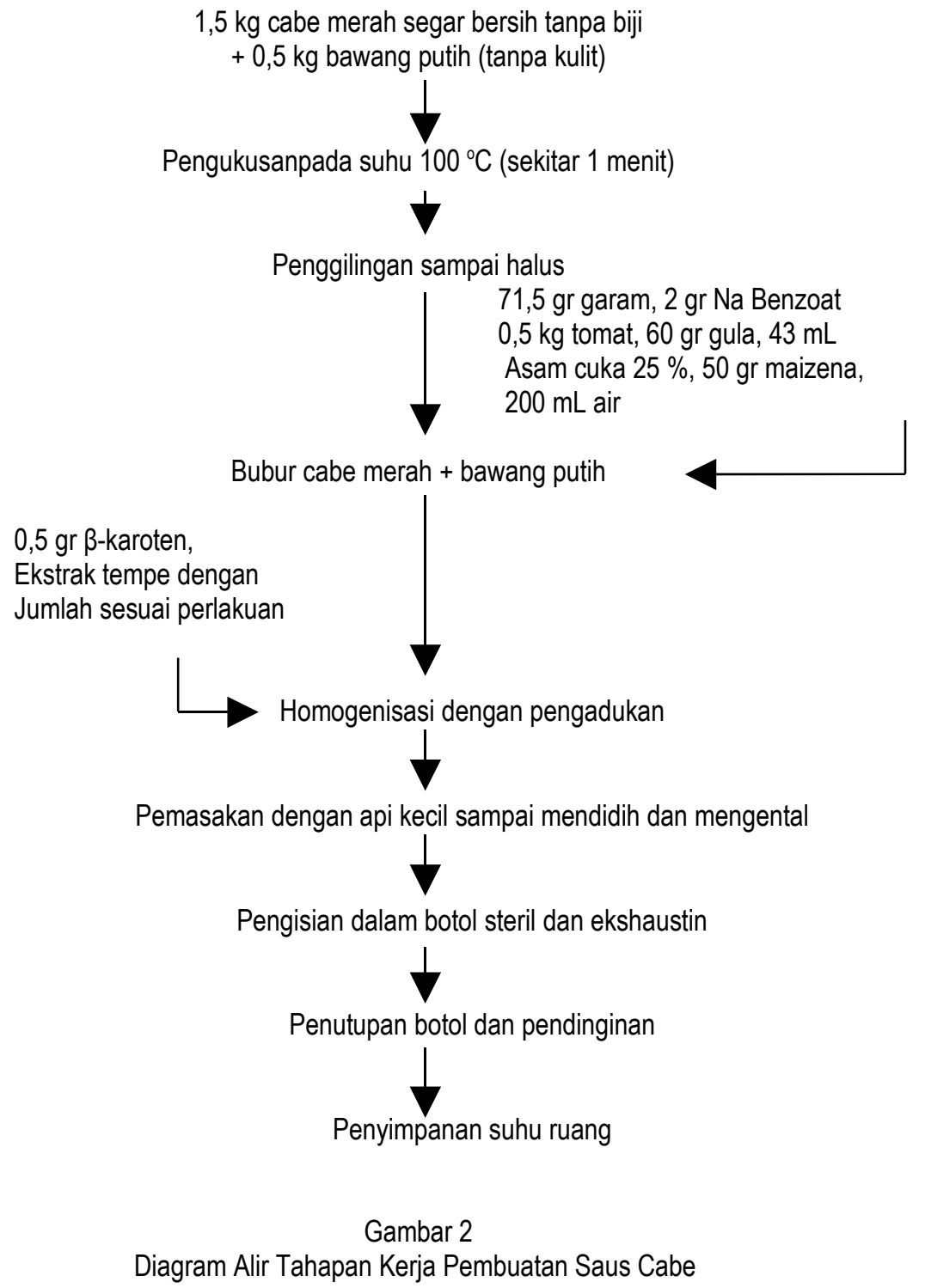




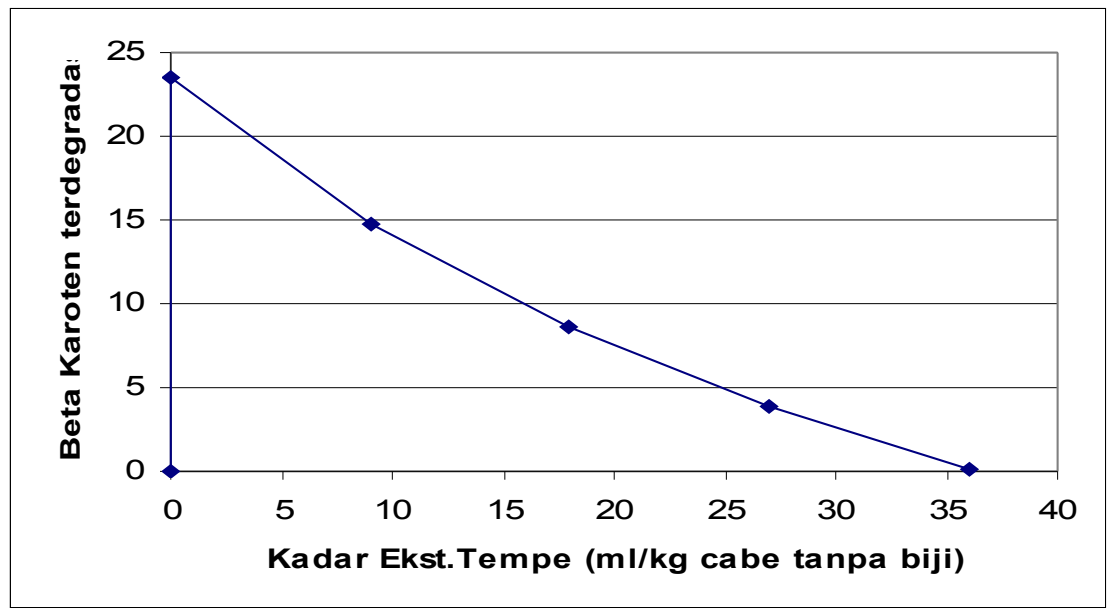

Gambar 3

Pola Perubahan B-karoten Relatif terhadap Ekstrak Tempe pada Pengolahan Saus Cabe dengan Pemanasan

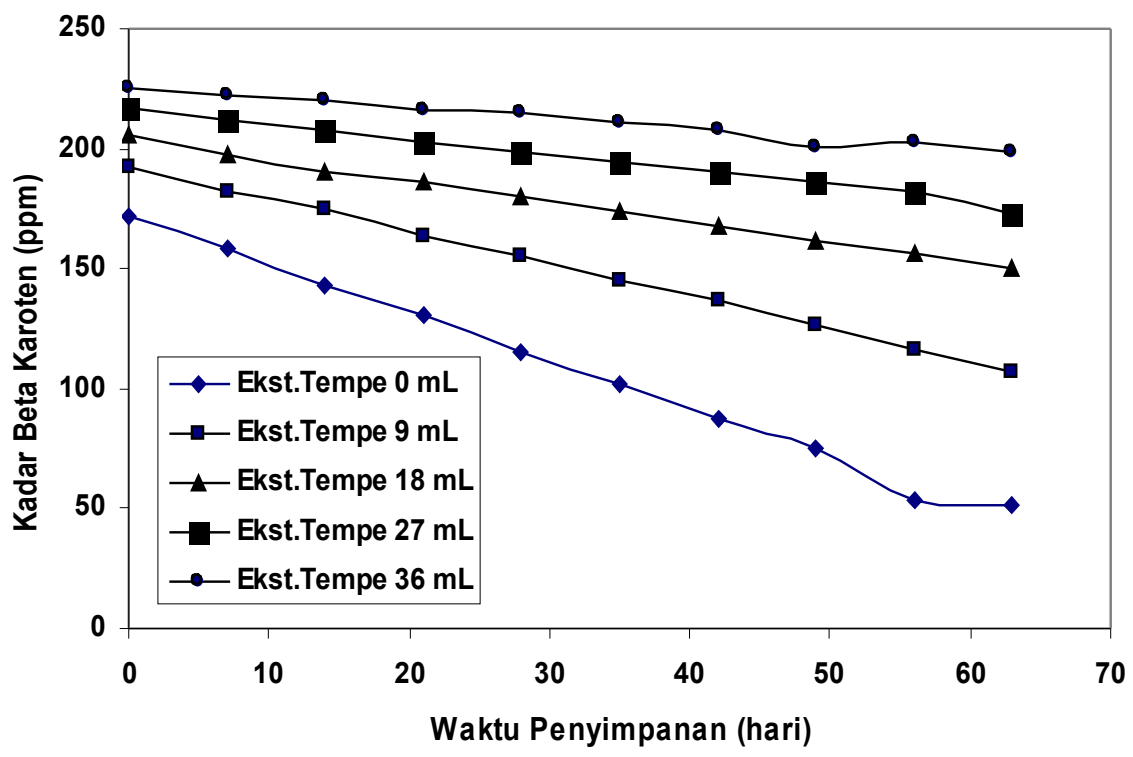

Gambar 4

Kurva Hubungan Antara Kadar B-karoten dalam Saus Cabe (ppm) dengan Waktu Penyimpanan (hari) 


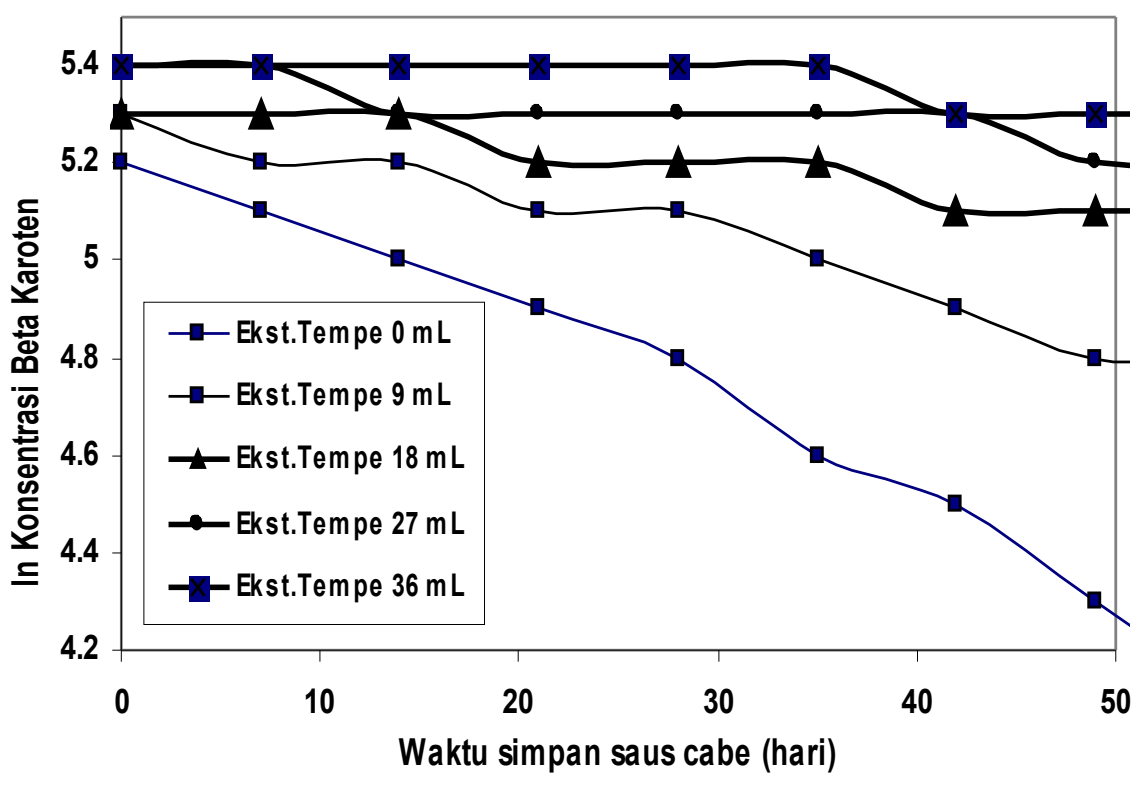

Gambar 5

Kurva Hubungan Antara In Konsentrasi B-karoten dalam Saus Cabe dengan Waktu Penyimpanan (hari)

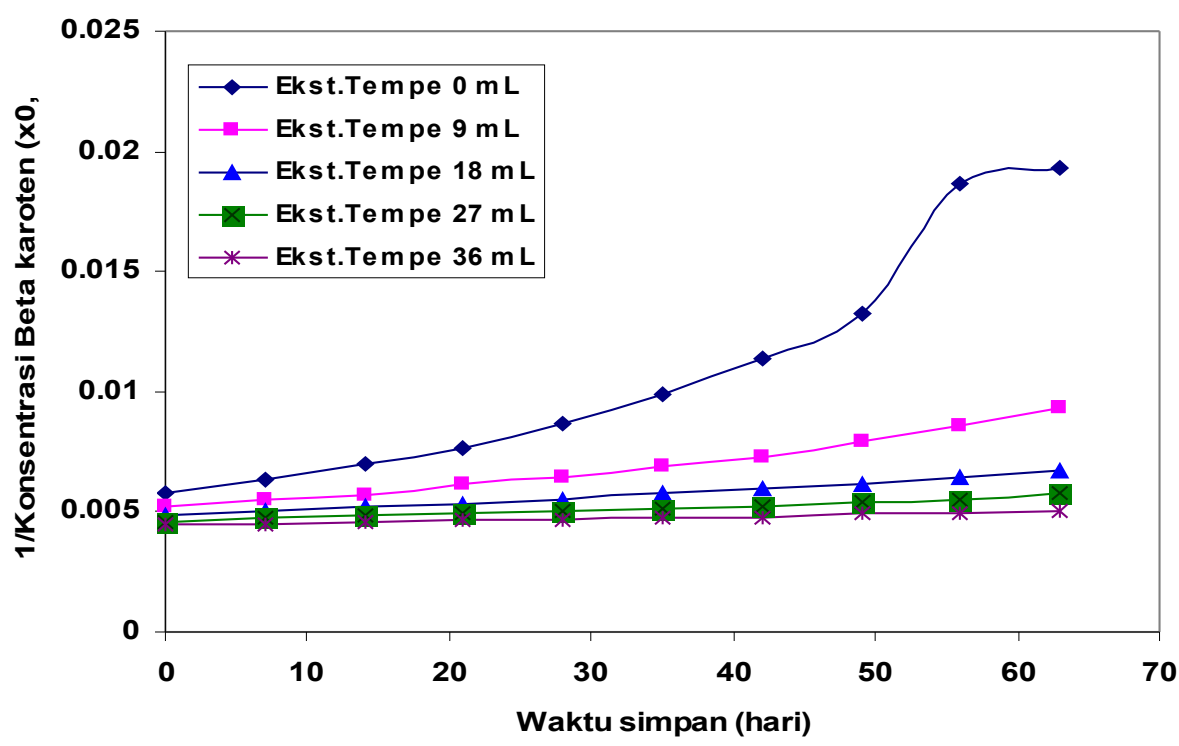

Gambar 6

Kurva Hubungan Antara 1/ Konsentrasi B-karoten Dalam Saus Cabe dengan Waktu Penyimpanan (hari) 
Tabel 1

Pengukuran Serapan Asam 3-hidroksi Antranilat Stándar dan Sampel (ekstrak tempe) pada Panjang Gelombang $300 \mathrm{~nm}$

\begin{tabular}{|c|c|c|}
\hline Kode contoh & Konsentrasi (ppm) & Nilai Absorbans \\
\hline A & 50 & 0,325 \\
B & 100 & 0,613 \\
C & 150 & 0,927 \\
D & 200 & 1,239 \\
E & 250 & 1,547 \\
Sampel & $236 \times 10$ (faktor pengenceran) & 1,457 \\
\hline
\end{tabular}

Keterangan:

$$
\begin{aligned}
& \mathrm{A}=\text { Ekstrak Tempe } 0 \mathrm{ml} \\
& \mathrm{B}=\text { Ekstrak Tempe } 9 \mathrm{ml} \\
& \mathrm{C}=\text { Ekstrak Tempe } 18 \mathrm{ml} \\
& \mathrm{D}=\text { Ekstrak Tempe } 27 \mathrm{ml} \\
& \mathrm{E}=\text { Ekstrak Tempe } 36 \mathrm{ml}
\end{aligned}
$$

Tabel 2

Perubahan B-karoten Dalam Saus Cabe Selama Pemanasan

\begin{tabular}{|c|c|c|c|c|}
\hline Perlakuan & $\begin{array}{c}\text { Ekstrak Tempe } \\
\text { (mL/kg cabe } \\
\text { Tanpa Bij) }\end{array}$ & $\begin{array}{c}\text { Kadar AHA } \\
\text { (mL/kg Cabe } \\
\text { Tanpa Biji) }\end{array}$ & $\begin{array}{c}\text { Kadar Beta } \\
\text { Karoten (ppm) }\end{array}$ & $\begin{array}{c}\text { B-karoten } \\
\text { Terdegradasi } \\
(\%)\end{array}$ \\
\hline K (Kontrol) & 0,00 & 0,00 & 225,30 & - \\
A & 0,00 & 0,00 & 172,21 & 23,56 \\
B & 9,00 & 21,24 & 192,00 & 14,78 \\
C & 18,00 & 42,48 & 205,91 & 8,61 \\
D & 27,00 & 63,72 & 216,60 & 3,86 \\
E & 36,00 & 84,96 & 224,90 & 0,18 \\
\hline
\end{tabular}

\section{Keterangan:}

$\mathrm{K}($ Kontrol $)=$ Ekstrak Tempe $0 \mathrm{~mL}$ tanpa pemanasan

$\mathrm{A}=$ Ekstrak Tempe $0 \mathrm{ml}$ dengan pemanasan

$B=$ Ekstrak Tempe $9 \mathrm{ml}$ dengan pemanasan

$C=$ Ekstrak Tempe $18 \mathrm{ml}$ dengan pemanasan

$\mathrm{D}=$ Ekstrak Tempe $27 \mathrm{ml}$ dengan pemanasan

$\mathrm{E}=$ Ekstrak Tempe $36 \mathrm{ml}$ dengan pemanasan 
Tabel 3

Kadar B-karoten dalam Saus Cabe Selama Penyimpanan Suhu Ruang

\begin{tabular}{|c|l|c|c|c|c|}
\hline \multirow{2}{*}{$\begin{array}{c}\text { Waktu } \\
\text { Penyimpanan } \\
\text { (hari) }\end{array}$} & \multicolumn{5}{|c|}{ Kadar B-karoten (mg/kg saus cabe Pada Perlakuan) } \\
\cline { 2 - 6 } & A & B & C & D & E \\
\hline 0 & 172,21 & 192,00 & 205,91 & 216,60 & 224,90 \\
7 & 158,30 & 182,40 & 198,00 & 211,68 & 221,80 \\
14 & 143,15 & 174,72 & 190,75 & 207,36 & 219,76 \\
21 & 130,90 & 163,20 & 186,55 & 203,00 & 216,50 \\
28 & 115,63 & 155,52 & 180,40 & 198,72 & 214,95 \\
35 & 101,59 & 145,00 & 174,25 & 194,60 & 211,00 \\
42 & 87,82 & 136,70 & 168,10 & 190,00 & 208,20 \\
49 & 75,60 & 126,80 & 162,00 & 186,00 & 205,10 \\
56 & 63,72 & 116,00 & 156,00 & 181,90 & 202,35 \\
63 & 51,76 & 107,50 & 149,75 & 172,80 & 198,95 \\
\hline
\end{tabular}

Keterangan:

$\mathrm{A}=$ Ekstrak Tempe $0 \mathrm{ml}$ dengan pemanasan

$\mathrm{B}=$ Ekstrak Tempe $9 \mathrm{ml}$ dengan pemanasan

$\mathrm{C}=$ Ekstrak Tempe $18 \mathrm{ml}$ dengan pemanasan

$\mathrm{D}=$ Ekstrak Tempe $27 \mathrm{ml}$ dengan pemanasan

$\mathrm{E}=$ Ekstrak Tempe $36 \mathrm{ml}$ dengan pemanasan

Tabel 4

Retensi B-karoten Dalam Saus Cabe Selama Penyimpanan Suhu Ruang

\begin{tabular}{|c|c|c|c|c|c|}
\hline \multirow{2}{*}{$\begin{array}{c}\text { Waktu } \\
\begin{array}{c}\text { Penyimpanan } \\
\text { (hari) }\end{array}\end{array}$} & \multicolumn{5}{|c|}{$\begin{array}{c}\text { Nilai Retensi B-karoten (\%) saus cabe } \\
\text { Selama Penyimpanan Pada Perlakuan }\end{array}$} \\
\cline { 2 - 6 } & A & B & C & D & E \\
\hline 7 & 91,92 & 95,00 & 96,16 & 97,73 & 98,62 \\
14 & 83,13 & 91,00 & 92,64 & 95,73 & 97,72 \\
21 & 76,01 & 85,00 & 90,60 & 93,72 & 96,27 \\
28 & 67,14 & 81,00 & 87,61 & 91,75 & 95,58 \\
35 & 58,99 & 75,52 & 84,62 & 89,84 & 93,82 \\
42 & 51,00 & 71,29 & 81,64 & 87,72 & 92,57 \\
49 & 43,90 & 66,04 & 78,68 & 85,87 & 91,20 \\
56 & 37,00 & 60,42 & 75,76 & 83,98 & 89,95 \\
63 & 30,06 & 55,99 & 72,73 & 79,78 & 88,46 \\
\hline
\end{tabular}

Keterangan:

$$
\begin{aligned}
& A=\text { Ekstrak Tempe } 0 \mathrm{ml} \\
& B=\text { Ekstrak Tempe } 9 \mathrm{ml} \\
& C=\text { Ekstrak Tempe } 18 \mathrm{ml} \\
& D=\text { Ekstrak Tempe } 27 \mathrm{ml} \\
& E=\text { Ekstrak Tempe } 36 \mathrm{ml}
\end{aligned}
$$


Tabel 5

Nilai Tetapan Laju Reaksi dan Persamaan Matematik Perubahan B-karoten Dalam Saus Cabe Pada Berbagai Konsentrasi Ekstrak Tempe

\begin{tabular}{|c|c|c|c|}
\hline $\begin{array}{c}\text { Kadar Ekstrak Tempe } \\
\text { (mL/kg Cabe tanpa } \\
\text { biji) dalam Saus Cabe }\end{array}$ & $\begin{array}{c}\text { Nilai Tetapan } \\
\text { Laju Reaksi } \\
(\mathrm{k})\end{array}$ & Nilai r & $\begin{array}{c}\text { Persamaan Matematik } \\
\text { Perubahan B-karoten } \\
\text { Dalam Saus Cabe }\end{array}$ \\
\hline 0,00 & 1,99 & 0,9998 & $\mathrm{~A}=171,84-1,99 \mathrm{t}$ \\
9,00 & 1,33 & 0,9995 & $\mathrm{~A}=192,12-1,33 \mathrm{t}$ \\
18,00 & 0,87 & 0,9985 & $\mathrm{~A}=204,60-0,87 \mathrm{t}$ \\
27,00 & 0,62 & 0,9998 & $\mathrm{~A}=216,21-0,62 \mathrm{t}$ \\
36,00 & 0,40 & 0,9975 & $\mathrm{~A}=225,04-0,40 \mathrm{t}$ \\
\hline
\end{tabular}

Tabel 6

Hasil Perhitungan dan Pengamatan Kadar B-karoten dalam Saus Cabe yang Tersimpan Selama 56 dan 63 hari

\begin{tabular}{ccccc}
\hline $\begin{array}{c}\text { Kadar Ekstrak Tempe } \\
\left(\begin{array}{c}\mathrm{mL} / \mathrm{kg} \text { cabe tanpa biji) } \\
\text { dalam Saus Cabe }\end{array}\right.\end{array}$ & $\begin{array}{c}\text { Waktu Simpan } \\
\text { Saus Cabe (hari) } \\
\text { Pada Suhu Ruang }\end{array}$ & $\begin{array}{c}\text { Kadar B-karoten } \\
\text { (ppm) Hasil } \\
\text { Pengamatan }\end{array}$ & $\begin{array}{c}\text { Kadar B-karoten } \\
\text { (ppm) } \\
\text { Hasil Perhitungan }\end{array}$ & $\begin{array}{c}\text { Derajat } \\
\text { Penyimpa } \\
\text { ngan } \\
(\%)\end{array}$ \\
\hline 0,00 & 56 & 63,72 & 60,4 & 5,21 \\
\hline 9,00 & 63 & 51,76 & 46,47 & 9,69 \\
\hline 18,00 & 56 & 116,00 & 117,64 & 1,41 \\
& 63 & 107,50 & 108,33 & 0,77 \\
\hline 27,00 & 56 & 156,00 & 155,88 & 0,07 \\
& 63 & 149,75 & 149,79 & 0,02 \\
\hline 36,00 & 56 & 181,90 & 181,49 & 0,02 \\
& 63 & 172,80 & 177,15 & 2,52 \\
\hline & 56 & 202,35 & 202,64 & 0,01 \\
\hline
\end{tabular}

